\title{
Uji Kepraktisan Perangkat Pembelajaran Matematika Berbasis Penemuan Terbimbing untuk SMP
}

\author{
Rena Revita \\ Jurusan Pendidikan Matematika, Universitas Islam Negeri Sultan Syarif Kasim Riau \\ e-mail: rena.revita@uin-suska.ac.id
}

\begin{abstract}
ABSTRAK. Penelitian ini bertujuan untuk mengetahui nilai kepraktisan perangkat pembelajaran matematika berbasis penemuan terbimbing. Penelitian ini dilakukan di SMP Negeri 1 Ampek Angkek Sumatera Barat pada materi teorema Pythagoras. Model pengembangan yang digunakan dalam mengembangkan perangkat ini adalah model pengembangan Plomp. Nilai akhir uji kepraktisan pada penelitian ini diperoleh melalui intrumen berupa angket respon guru dan angket respon peserta didik sebagai pengguna pada uji lapangan dan dianalisis dengan teknik analisis data kuantitatif. Hasil penelitian yang diperoleh melalui angket respon guru dihasilkan nilai rata-rata kepraktisan yaitu 85,45\% dengan kategori sangat praktis. Sedangkan dari angket respon peserta didik dihasilkan nilai rata-rata kepraktisan yaitu $87,14 \%$ dengan kategori sangat praktis. Setelah melalui beberapa proses dan berdasarkan kategori-kategori tersebut, maka perangkat pembelajaran matematika berbasis penemuan terbimbing yang dikembangkan memiliki kategori sangat praktis menurut guru dan peserta didik sebagai pengguna.
\end{abstract}

Kata kunci: Penemuan Terbimbing, Perangkat Pembelajaran Matematika, Uji Kepraktisan.

\section{PENDAHULUAN}

Matematika merupakan ilmu penting yang harus dikuasai untuk meningkatkan kemampuan dan keterampilan intelektual peserta didik. Untuk itu matematika menjadi mata pelajaran yang wajib dipelajari oleh peserta didik di sekolah mulai dari tingkat sekolah dasar hingga tingkat perguruan tinggi. Dalam proses pembelajaran di kelas, Noviarni (2014) mengatakan bahwa Pembelajaran matematika merupakan proses memperoleh pengetahuan atau kemamapuan yang dibangun oleh peserta didik sendiri dan harus dilakukan sedemikian rupa sehingga dapat memberikan kesempatan bagi peserta didik untuk menemukan kembali konsep-konsep yang diinginkan dalam proses pembelajaran. Oleh karena itu, penting bagi seorang guru atau pendidik untuk menciptakan proses belajar matematika yang bermakna dan menyenangkan bagi peserta didik agar tercapainya tujuan belajar matematika yang diinginkan.

Proses pembelajaran matematika yang baik akan mendukung tercapainya hasil belajar yang efektif. Untuk itu, terdapat beberapa prinsip pembelajaran yang harus dipenuhi agar tercapainya hasil belajar yang efektif, seperti menurut Kosasih (2014), dalam proses pembelajaran terdapat prinsip-prinsip belajar yang harus terpenuhi diantaranya Berpusat pada peserta didik, mengembangkan kreativitas peserta didik, menciptakan kondisi menyenangkan dan menantang, bermuatan nilai, etika, estetika, logika, dan kinestetika, menyediakan pengalaman belajar yang beragam melalui penerapan berbagai strategi pembelajaran dan model pembelajaran yang menyenangkan, kontekstual, efektif, efisien dan bermakna.

Berdasarkan prinsip-prinsip tersebut, terdapat prinsip yaitu menyediakan pengalaman belajar yang beragam. Pengalaman belajar yang beragam dapat dirancang oleh guru dan direncanakan dalam perangkat pembelajaran yang dipersiapkan sebelum memulai pembelajaran dikelas. Sebelum melakukan dan melaksanakan pembelajaran guru harus membuat dan memiliki perangkat pembelajaran. Sebagaimana yang dsebutkan didalam Permendikbud No. 22 Tahun 2016 yang membahas tentang penyusunan perangkat pembelajaran dalam bentuk Rencana 
Pelaksanaan Pembelajaran (RPP) dan silabus yang berdasarkan standar isi. Adanya perangkat ini menjadikan guru semakin bertambah professional dan lebih terbantu dengan hal-hal yang terprogram. Menurut Noviarni (2014) diantara beberapa perangkat pembelajaran yang harus dipersiapkan guru sebelum melaksanakan pembelajaran adalah silabus, RPP, Bahan Ajar dan Instrumen Penilaian.

Guru dapat merencanakan proses pembelajaran yang akan dilakukannya di dalam Rencana Pelaksanaan Pembelajaran (RPP) dengan menerapkan strategi maupun model pembelajaran yang dapat menciptakan pembelajaran yang menyenangkan, kontekstual, efektif, efisien dan bermakna. RPP dapat dikembangkan oleh guru dengan menerapkan berbagai model atau strategi yang dapat disesuaikan dengan materi dan kondisi peserta didik. Diantara model yang dapat diterapkan adalah model Pembelajaran Penemuan Terbimbing.

Menurut Risnawati (2008) model penemuan terbimbing merupakan suatu cara penyampaian topik matematika sedemikian rupa sehingga dalam proses belajar memungkinkan peserta didik menemukan sendiri pola-pola atau struktur-struktur matematika melalui serentetan pengalaman belajar yang lampau dan tidak lepas dari pengawasan serta bimbingan guru. Selain itu, menurut Hamalik (Nurcholis, 2013), menyatakan bahwa model penemuan terbimbing adalah suatu prosedur mengajar yang menitikberatkan studi individual, manipulasi objek-objek, dan eksperimentasi oleh peserta didik sebelum membuat generalisasi sampai peserta didik menyadari suatu konsep. Berdasarkan definisi-definisi tersebut, dapat diketahui bahwa dalam model penemuan terbimbing peserta didik melakukan penemuan secara sendiri prinsip/prosedur matematika dalam konsep yang dipelajari, sedangkan guru membimbing mereka ke arah yang akan dituju dengan benar sesuai dengan tujuan pmbelajaran .

Menurut Suherman (2001), pada penemuan terbimbing seorang guru memberikan petunjuk, arahan-arahan, pernyataan-pernyataan atau dialog sampai pada suatu kesimpulan tentang materi yang diajarkan, bimbingan diberikan guru tergantung dengan kemampuan peserta didik dan topik yang diajarkan. Selain itu menurut Atencio (Hariyani, 2010) menyatakan bahwa bimbingan guru dapat membangun ketertarikan dan pemahaman peserta didik. Selanjutnya menurut pendapat Ratumanan (Hariyani, 2010), bimbingan guru yang dimaksud adalah memberikan bantuan agar peserta didik dapat memahami tujuan kegiatan yang dilakukan dan berupa arahan tentang prosedur kerja yang perlu dilakukan dalam kegiatan pembelajaran. Didukung oleh pernyataan Nurcholis (2013) yang menyatakan bahwa bimbingan tersebut diberikan melalui serangkaian pertanyaan atau lembar kegiatan dalam proses pembelajaran. Berdasarkan uraian tersebut, dapat diketahui bahwa melalui proses penemuan terbimbing ini, peserta didik dituntut untuk menggunakan ide dan pemahaman yang telah dimiliki untuk menemukan sesuatu yang baru dari konsep yang sudah ada, sehingga pemahaman matematis peserta didik dapat meningkat. Dengan demikian pembelajaran dengan model penemuan terbimbing memungkinkan peserta didik memahami apa yang dipelajari dengan baik.

Untuk pelaksanaan model penemuan terbimbing di dalam kelas, terdapat langkah-langkah yang harus dilaksanakan. Langkah-langkah yang harus dilakukan dalam menggunakan model penemuan terbimbing menurut Markaban (2008) adalah sebagai berikut:

a. Merumuskan masalah yang akan diberikan kepada peserta didik dengan data secukupnya, perumusannya harus jelas, hindari pernyataan yang menimbulkan salah tafsir sehingga arah yang ditempuh peserta didik tidak salah.

b. Dari data yang diberikan guru, peserta didik menyusun, memproses, mengorganisir, dan menganalisis data tersebut. Dalam hal ini, bimbingan guru dapat diberikan sejauh mana yang dibutuhkan peserta didik. Bimbingan ini sebaiknya mengarahkan peserta didik untuk melangkah ke arah yang hendak dituju, melalui pertanyaan-pertanyaan atau LKPD.

c. Peserta didik menyusun konjektur (prakiraan) dari hasil analisis yang dilakukannya.

d. Bila dipandang perlu, konjektur yang telah dibuat oleh peserta didik tersebut di atas diperiksa oleh guru. Hal ini penting dilakukan untuk meyakinkan kebenaran prakiraan peserta didik, sehingga akan menuju arah yang akan dicapai. 
e. Apabila telah diperoleh kepastian tentang kebenaran konjektur tersebut, maka verbalisasi konjektur sebaiknya diarahkan juga kepada peserta didik untuk menyusunnya.

f. Sesudah peserta didik menemukan apa yang dicari, hendaknya guru menyediakan soal latihan atau soal tambahan untuk memeriksa apakah hasil penemuan itu benar.

Sebagai sebuah model, penemuan terbimbing terdapat beberapa kelebihan. Kelebihan model pembelajaran penemuan terbimbing, sebagaimana yang disebutkan oleh Suherman (2001) beberapa kelebihan dari model penemuan terbimbing adalah :

a. Peserta didik aktif dalam kegiatan belajar, sebab ia berfikir dan menggunakan kemampuan untuk menemukan hasil akhir,

b. Peserta didik memahami benar bahan pelajaran sebab mengalami sendiri proses menemukannya.

c. Sesuatu yang diperoleh dengan cara ini lebih lebih lama diingat, Menemukan sendiri menimbulkan rasa puas. Kepuasan batin ini mendorong melakukan penemuan lagi hingga minat belajarnya meningkat,

d. Peserta didik yang memperoleh pengetahuan dengan metode penemuan akan lebih mampu mentransfer pengetahuannya ke berbagai konteks.

e. Metode ini melatih peserta didik untuk lebih banyak belajar sendiri.

Model penemuan terbimbing selain memiliki kelebihan-kelebihan juga memiliki kekurangan-kekurangan. Seperti yang dijelaskan oleh Markaban (2008), kekurangan dari model penemuan terbimbing yaitu untuk materi tertentu waktu yang tersita cukup banyak, tidak semua peserta didik dapat mengikuti pelajaran ini dengan cara ini serta tidak semua topik cocok disampaikan dengan model ini.

Selain mengembangkan kegiatan pembelajaran di dalam RPP melalui penerapan model pembelajaran penemuan terbimbing, seorang guru juga harus dapat mempersiapkan bahan ajar yang akan digunakan oleh peserta didik dan dapat menujang jalannya proses pembelajaran di dalam kelas. Untuk itu perlu bagi guru mengembangkan bahan ajar sendiri sesuai dengan tingkat pemahaman peserta didik yang diajar. Salah satu bahan ajar yang dapat dirancang oleh guru adalah bahan ajar Lembar Kerja Peserta Didik (LKPD).

LKPD merupakan salah satu bahan ajar yang dapat membantu peserta didik dalam mencapai tujuan pembelajaran. Menurut Trianto (2009), lembar kegiatan peserta didik merupakan panduan peserta didik yang digunakan untuk melakukan kegiatan penyelidikan atau pemecahan masalah. Lembar kegiatan ini dapat berupa panduan untuk latihan pengembangan aspek kognitif maupun panduan untuk pengembangan aspek pembelajaran dalam bentuk eksperimen atau demonstrasi di dalam kelas. Sementara menurut Prastowo (2011), LKS merupakan materi ajar yang sudah dikemas sedemikian rupa sehingga peserta didik diharapkan dapat mempelajari materi ajar tersebut secara mandiri di dalam kelas. Berdasarkan beberapa pendapat tersebut, dapat disimpulkan bahwa LKPD merupakan salah satu perangkat pembelajaran yang berisikan materi ajar yang sudah dikemas sedemikian rupa, yang di dalamnya juga berisikan rangkaian aktivitas atau kegiatan dalam menemukan kembali prinsip dan prosedur pelajaran dan dapat digunakan peserta didik baik secara berkelompok maupun secara individu.

LKPD yang dirancang dengan memiliki ketentuan sesuai dengan langkah-langkah penemuan terbimbing yang dijelaskan oleh Markaban (2008) yaitu pada tahap awal LKPD peserta didik diberikan masalah yang berkaitan sesuai dengan materi pelajaran oleh guru secara jelas dan lengkap. Kemudian peserta didik diberikan langkah-langkah untuk dapat membangun pemahamannya dengan menyusun, memproses dan mengorganisir informasi yang diperoleh serta melakukan analisis sehingga peserta didik mampu memahami materi yang dipelajari dan dapat memecahkan persoalan yang berkaitan dengan materi tersebut. Menurut Effendi (2012), dalam penemuan terbimbing guru hanya sebagai fasilitator yang membimbing peserta didik melalui pertanyaan-pertanyaan yang mengarahkan peserta didik dalam proses penemuan".

Berdasarkan uraian tersebut, maka peneliti melakukan penelitian pengembangan perangkat 
pembelajaran matematika yang dalam hal ini dibatasi pada pengembangan RPP dan Bahan Ajar LKPD dengan menerapkan model pembelajaran Penemuan Terbimbing. Hal yang menjadi fokus kajian bagi penelitian adalah bagaimana sebuah perangkat memiliki nilai kepraktisan yang baik, sehingga dapat digunakan oleh peserta didik maupun guru di sekolah. Nilai kepraktisan tersebut diperoleh dengan melihat apakah aspek-aspek kepraktisan dapat terpenuhi oleh perangkat yang dkembangkan. Aspek-aspek kepraktisan tersebut yaitu menurut pendapat Sukardi (2008) yang menyatakan bahwa kepraktisan dapat dilihat dalam aspek-aspek berikut:

a. Penggunaan, meliputi mudah diatur, disimpan, dan dapat digunakan sewaktu-waktu.

b. Waktu yang diperlukan dalam pelaksanaan sebaiknya singkat, cepat dan tepat.

c. Daya tarik perangkat terhadap minat peserta didik.

d. Mudah diinterpretasikan oleh guru, ahli maupun peserta didik.

e. Memiliki ekivalensi yang sama sehingga bisa digunakan sebagai pengganti atau variasi.

Oleh karena itu rumusan masalah dalam penelitian ini adalah bagaimana nilai kepraktisan perangkat pembelajaran matematika berbasis penemuan terbimbing yang dikembangkan untuk peserta didik kelas VIII SMP Pada materi Teorema Pythagoras?

\section{METODE}

Penelitian ini merupakan penelitian pengembangan esearch and development) yaitu penelitian yang dilakukan untuk menghasilkan produk tertentu, dan menguji keefektifan produk tersebut, (Sugiyono, 2012). Menurut Gay (Oktaviandy, 2012), penelitian pengembangan adalah suatu usaha untuk mengembangkan suatu produk yang efektif untuk digunakan sekolah, dan bukan untuk menguji teori. Produk tersebut dapat berupa perangkat pembelajaran yaitu LKPD, modul, handout atau pun program dengan menggunakan komputer.

Dalam penelitian ini, produk yang dikembangkan oleh peneliti adalah perangkat pembelajaran matematika berupa Rencana Pelaksanaan Pembelajaran (RPP) dan Lembar Kegiatan Peserta Didik (LKPD) yang berbasis model penemuan terbimbing untuk materi teorema Pythagoras kelas VIII SMP. Model penelitian pengembangan yang digunakan adalah model pengembangan Plomp. Model ini dikembangkan oleh Tjeerd Plomp yang terdiri dari 3 tahapan, yaitu tahap investigasi awal (preliminary research), tahap pengembangan atau pembuatan prototipe (development or prototyping phase) dan tahap penilaian (assessment phase), (Plomp and Nieveen, 2013).

Pada produk RPP dan LKPD berbasis penemuan terbimbing yang dikembangkan, nilai kepraktisan diperoleh dari hasil intrumen pengumpulan data berupa angket respon yang diisi oleh guru dan peserta didik sebagai pengguna pada uji lapangan. Adapun aspek yang akan menjadi penilaian pada uji kepraktisan produk ini menurut Sukardi (2008) yaitu:

a. Penggunaan, meliputi mudah diatur, disimpan, dan dapat digunakan sewaktu-waktu.

b. Waktu yang diperlukan dalam pelaksanaan sebaiknya singkat, cepat dan tepat.

c. Daya tarik perangkat terhadap minat peserta didik.

d. Mudah diinterpretasikan oleh guru, ahli maupun peserta didik.

e. Memiliki ekivalensi yang sama sehingga bisa digunakan sebagai pengganti atau variasi.

Berdasarkan uraian tersebut, praktikalitas perangkat pembelajaran dilihat dari beberapa aspek yaitu kemudahan penggunaan perangkat pembelajaran bagi guru maupun peserta didik, waktu yang diperlukan, keterbacaan perangkat dan penyajian perangkat pembelajaran yang dikembangkan tersebut dalam proses pembelajaran di kelas.

Angket yang telah diisi oleh guru dan peserta didik tersebut akan dianalisis dengan menggunakan analisis kuantitatif sehingga diperoleh nilai rata-rata untuk ditentukan kategori kepraktisan dari perangkat pembelajaran yang dikembangkan. 


\section{HASIL}

Nilai kepraktisan perangkat pembelajaran matematika dilihat dari hasil analisis angket yang diisi oleh guru dan peserta didik sebagai pengguna pada saat uji lapangan. Berikut ini akan dideskripsikan hasil analisis terhadap masing-masing instrumen tersebut.

a. Hasil Angket Respon Guru

Angket kepraktisan yang diisi oleh guru bertujuan untuk mendapatkan informasi mengenai kepraktisan perangkat pembelajaran berdasarkan prediksi dan pertimbangan guru setelah menggunakan perangkat selama proses pembelajaran. Secara umum hasil angket kepraktisan yang diisi oleh guru dapat dilihat pada Tabel 1 berikut.

Tabel 1. Data Hasil Angket Respon Guru

\begin{tabular}{llcc}
\hline No. & Aspek yang dinilai & Nilai kepraktisan (\%) & Kategori \\
\hline 1. & Penyajian & $100 \%$ & Sangat praktis \\
2. & Penggunaan & $91,9 \%$ & Sangat praktis \\
3. & Keterbacaan & $75 \%$ & Praktis \\
4. & Waktu & $75 \%$ & Praktis \\
\multicolumn{2}{l}{ Nilai rata-rata kepraktisan } & $85,45 \%$ & Sangat praktis \\
\hline
\end{tabular}

b. Hasil Angket Respon Peserta Didik

Angket kepraktisan ini diberikan kepada peserta didik setelah mengikuti proses pembelajaran menggunakan LKPD berbasis penemuan terbimbing. Secara keseluruhan hasil angket kepraktisan yang diisi oleh peserta didik dapat dilihat pada Tabel 2 berikut.

Tabel 2. Data Hasil Angket Respon Peserta Didik

\begin{tabular}{llcc}
\hline No. & Aspek yang dinilai & Nilai kepraktisan (\%) & Kategori \\
\hline 1. & Penyajian & $89 \%$ & Sangat praktis \\
2. & Penggunaan & $86,45 \%$ & Sangat praktis \\
3. & Keterbacaan & $85,48 \%$ & Sangat praktis \\
4. & Waktu & $85,3 \%$ & Sangat praktis \\
\multicolumn{2}{l}{ Nilai rata-rata kepraktisan } & $87,14 \%$ & Sangat praktis \\
\hline
\end{tabular}

\section{PEMBAHASAN}

Kepraktisan perangakat pembelajaran matematika berbasis penemuan terbimbing ini dilihat melalui angket yang diisi oleh guru dan peserta didik sebagai pengguna perangkat pembelajaran yang dikembangkan Aspek-aspek yang dilihat untuk kepraktisan perangkat pembelajaran matematika berbasis penemuan terbimbing ini adalah aspek penyajian, penggunaan, keterbacaan dan waktu.

Berdasarkan angket yang diisi oleh guru perangkat pembelajaran memperoleh nilai kepraktisan yaitu 100\% untuk aspek penyajian dengan kategori sangat praktis, 91,9\% untuk aspek penggunaan dengan kategori sangat praktis, 75\% untuk aspek keterbacaan dengan kategori praktis dan $75 \%$ untuk aspek waktu dengan kategori praktis. Berdasarkan kategori-kategori tersebut secara keseluruhan perangkat pembelajaran berbasis penemuan terbimbing ini memperoleh nilai rata-rata kepraktisan yaitu 85,45\% dari hasil angket yang diisi oleh guru dengan kategori sangat praktis. Hal tersebut menunjukkan bahwa perangkat pembelajaran matematika berbasis penemuan terbimbing sudah praktis menurut guru sebagai pengguna. Selain itu menurut guru LKPD berbasis penemuan terbimbing ini sudah bagus dan juga sudah menarik untuk digunakan dalam proses pembelajaran.

Berdasarkan angket yang diisi oleh peserta didik LKPD berbasis penemuan terbimbing memperoleh nilai kepraktisan yaitu $89 \%$ untuk aspek penyajian dengan kategori sangat praktis, $86,45 \%$ untuk aspek penggunaan dengan kategori sangat praktis, 85,48\% untuk aspek 
keterbacaan dengan kategori sangat praktis dan 85,3\% untuk aspek waktu dengan kategori sangat praktis. Secara keseluruhan LKPD berbasis penemuan terbimbing memperoleh nilai kepraktisan yaitu $87,14 \%$ dengan kategori sangat praktis.

Berdasarkan angket yang telah diisi oleh peserta didik tersebut, dari segi penyajian perangkat pembelajaran matematika berbasis penemuan terbimbing ini sudah menarik karena terdiri dari warna-warna yang menarik perhatian para peserta didik serta gambar dan ilustrasi pada LKPD membantu peserta didik dalam memahami materi mengenai teorema pythagoras. Dari segi penggunaan, bagi peserta didik LKPD berbasis penemuan terbimbing sudah mudah digunakan, mudah dibawa dan guru menyarankan kepada peserta didik agar meninggalkan buku cetak dan membawa LKPD saja untuk mengurangi beban yang ada pada tas peserta didik dikarenakan menurut guru LKPD teorema Pythagoras berbasis penemuan terbimbing sudah lengkap, selain itu soal-soal yang terdapat di dalam LKPD juga dapat diselesaikan dengan baik oleh peserta didik. Dari segi keterbacaan menurut peserta didik LKPD berbasis penemuan terbimbing ini sudah sangat jelas untuk dibaca. Menurut peserta didik waktu yang ditentukan dalam pengerjaan LKPD berbasis penemuan terbimbing ini sudah cukup. Hal ini berarti LKPD berbasis penemuan terbimbing sudah praktis menurut guru dan peserta didik sebagai pengguna.

\section{KESIMPULAN}

Perangkat pembelajaran matematika berbasis penemuan terbimbing dapat dikatakan praktis berdasarkan data kepraktisan akhir yang diperoleh dari hasil angket respon guru dan peserta didik sebagai pengguna pada uji lapangan. Dari angket respon yang diisi oleh guru dihasilkan nilai ratarata kepraktisan yaitu 85,45\% dengan kategori sangat praktis. Sedangkan dari angket respon yang diisi oleh peserta didik dihasilkan nilai rata-rata kepraktisan yaitu 87,14\% dengan kategori sangat praktis. Setelah melalui beberapa proses dan berdasarkan kategori-kategori tersebut, maka perangkat pembelajaran matematika berbasis penemuan terbimbing yang dikembangkan memiliki kategori sangat praktis menurut guru dan peserta didik sebagai pengguna. Ini berarti perangkat pembelajaran matematika sudah praktis dan layak untuk digunakan dalam proses pembelajaran di kelas.

\section{REFERENSI}

Effendi, L. A. (2012). Pembelajaran Matematika dengan Metode Penemuan Terbimbing Untuk Meningkatkan Kemampuan Representasi dan Pemecahan Masalah Matematis Siswa SMP. Jurnal Penelitian Pendidikan, 13(2), 1-10.

Hariyani, Mimi. (2010). Pembelajaran Matematika Dengan Metode Penemuan Terbimbing untuk Meningkatkan Pemahaman Konsep dan Kemampuan Penalaran Matematik Siswa Sekolah Dasar. Tesis UPI Bandung. Tidak Diterbitkan.

Kosasih. (2014). Strategi Belajar dan Pembelajaran Implementasi Kurikulum 2013. Bandung: Yrama Widya.

Markaban. (2008). Model Penemuan Terbimbing pada Pembelajaran Matematika SMK. Yogyakarta: Pusat Pengembangan dan Pemberdayaan Pendidik dan Tenaga Kependidikan Matematika.

Noviarni. (2014). Perencanaan Pemebelajaran Matematika dan Aplikasinya Menuju Guru Matematika yang Kreatif dan Inovatif. Pekanbaru : Benteng Media.

Nurcholis. (2013). Implementasi Metode Penemuan Terbimbing untuk Meningkatkan Hasil Belajar Siswa pada Penarikan Kesimpulan Logika Matematika. Jurnal Elektronik Pendidikan Matematika Tadulako, 01(01), 32-42. 
Oktaviandy, N. (2012). Penelitian Pengembangan (Development Research), tersedia : https:// navelmangelep.wordpress.com/2012/04/01/penelitian-pengembangan-development-research/ [26 Januari 2016].

Prastowo, A. (2012). Panduan Kreatif Membuat Bahan Ajar Inovatif. Jogjakarta: DIVA Press.

Plomp, T dan N. Nieveen. 2013. Education Design Research. Enshede: Netherlands Institute For Curriculum Development (SLO).

Risnawati. (2008). Strategi Pembelajaran Matematika. Pekanbaru: Suska Press.

Sugiyono. (2012). Metode Penelitian Pendidikan; Pendekatan Kuantitatif, dan R\&D. Alfabeta: Bandung.

Suherman, E. (2001). Startegi Pembelajaran Matematika Komtemporer. JICA. UPI Bandung.

Sukardi. (2008). Evaluasi Pendidikan Prinsip \& Operasionalnya. Jakarta: Bumi Aksara.

Trianto. (2009). Mendesain Model Pembelajaran Inovatif-Progresif. Jakarta: Kencana. 